\title{
SYMPATHY FOR THE DEVIL?
}

\section{AUSTRALIAN UNIONISM AND PUBLIC OPINION}

David Peetz

School of Industrial Relations

Griffith University

Brisbane Qld 4111

and visiting fellow

University of New South Wales, Sydney 2052.

E-mail: D.Peetz@mailbox.gu.edu.au

Tel: 0293857177

Fax: 0296628531

David Peetz is associate professor in industrial relations at Griffith University. 
SYMPATHY FOR THE DEVIL?

AUSTRALIAN UNIONISM AND PUBLIC OPINION

\section{Abstract}

Public opinion on trade unions is influenced by a variety of factors, including direct experiences of industrial conflict, socialisation, the consonance of union behaviour with values and norms, and the general climate of debate, opinion and propaganda. Union sympathy (general support for unions): slowly declined between the 1940s and the 1960s; deteriorated sharply during the early 1970s; and recovered slowly under the Accord. The deterioration after the 1940s may be attributable to anti-communism's association with antiunionism. The deterioration during the 1970s was associated with a significant rise in industrial conflict and the slow improvement in sympathy during the 1980s and 1990s was probably linked to the Accord-related fall in it. The decline in union density since the early 1980s cannot be directly attributed to a shift in union sympathy. Despite low levels of disputation in the late 1990s, though, union sympathy then appeared weaker than in the 1940s. Its low level in Australia, compared to other countries, may partly reflect the influence of anti-communism, but especially of arbitration, which rendered strikes illegitimate. 


\section{SYMPATHY FOR THE DEVIL?}

\section{AUSTRALIAN UNIONISM AND PUBLIC OPINION}

The significant decline in union membership over the 1990s, and in union density (membership as a proportion of all employees) since the late 1970s, is thought by many commentators to reflect or proxy a broader weakening of sympathy towards unionism in general (eg Rawson 1983). This article examines trends in union sympathy in Australia and how recent patterns in Australia compare with those in other countries. In this paper, the term 'union sympathy' is used to describe the general views about unions held by people (as opposed to their direct personal experiences of the gains or losses from union membership).

This paper presents data that extend the analysis in Peetz (1998). The existing literature, summarised there, indicates that union sympathy does affect union membership, but that it is not commonly the sole or even most important determinant. That study also distinguished between the reasons people have for joining and for leaving unions, and showed that union sympathy is an influential factor helping determine whether people join unions, but has only a limited effect on whether people leave unions once they are members (Peetz 1998). In relation to joining, it showed that antipathy towards unions could be a strong influence preventing people joining unions. Given that union sympathy influences union membership, this paper considers two major issues: how has union sympathy changed over time; and what can we learn from examining Australian union sympathy in an international context? Our interest here is in understanding union sympathy, not union density, though we will also touch on the implications of trends in union sympathy for understanding changes in union density. 
Our method for investigating the first question is to analyse data from published opinion polls, undertaken by commercial organisations (Morgan Gallup Poll, Australian Public Opinion Polls, Age Poll, Newspoll) or academic institutions (the National Social Science Surveys, International Social Science Surveys, Australian Election Surveys, and Australian Political Attitude Surveys, conducted mainly through the Australian National and Macquarie Universities) over the period from the 1940s to the 1990s, with most of the emphasis on the last two decades. To investigate the second question, we use opinion poll data from Australia and other countries where comparisons are possible.

There is, unfortunately, no single time series source for public opinion on unions, so we are forced to rely on data concerning several aspects of union sympathy from these several sources. The above surveys generally use 'all Australian adults' as the population from which samples are drawn, and so enable comparisons over time to take place. Different surveys also tend to use differently worded questions. We have therefore relied on polls where the questions are phrased sufficiently closely as make the effect of differences in wording minimal. Often exactly the same question is repeated on occasions many years apart. The combined impact of sampling error and minor differences in question wording is to introduce 'white noise' into the data but, as will be seen, the trends that are observed over time are sufficiently large as to be unattributable to these disturbances in the data. We present the data in the form of bar charts in the text; the numbers underpinning the bar charts, and the sources, question wordings and sample sizes, are shown in the appendix.

Before discussing these analyses, however, we paint a brief historical picture of the industrial and political context in which changes in public opinion should be observed. This is not a history of post-war politics and industrial relations, but rather an overview of some of those 
trends which may be relevant to the development of public opinion. We focus on: the rise and fall of anti-communism; the norms of arbitration; and the level of industrial disputation.

\section{Historical context}

'Public opinion' as measured by surveys or polls reflects a variety of forces: socialisation through family, religion, class, peers, education and the community; the direct experiences of individuals; the interpretation of events as portrayed in the media; and public debate, information and propaganda conducted by or disseminated through opinion leaders such as politicians, commentators and the media; and the immediate context in which questions are asked (Albig 1956; Childs 1964; Schwartz 1966; Bogart 1977; Oskamp 1977; Hunt 1978; Weimann 1991; Jordan 1993; Mutz 1997). We do not attempt here to deal with the impact of changes in each of these areas. For example, changes in socialisation through education are beyond the scope of this paper (though also likely to be of minor importance, as the education syllabus has rarely given priority to union or industrial relations issues). Rather, in looking to understand changes in sympathy towards unions we focus on particular events that may have directly affected people or have been interpreted for them through the media, and touch on the role of propaganda and public debate.

We are not attempting to argue here that public opinion is 'objectively' measured by polls: as exemplified later, the responses people give to polls reflect in part the way the questions are worded. Our intent here is not so much to assert in an absolute sense how public opinion regarding trade unions can be characterised, but to see how it has changed over time and how any changes relate to other developments. For example, on union power, we do not try to conclude that Australians would be happier if unions had less power, merely on the strength of a 
finding that the majority of Australians agree with a statement that Australian unions have too much power. Approaching the question a different way - asking people if they would prefer that unions in their workplace had more influence - would yield quite different results (Peetz 1996), and indeed could suggest that Australians would be less happy if unions were weaker. Instead, our interest is in making comparisons over time between several polls with broadly similar wording on, for example, whether unions have too much power - to determine whether this aspect of overall sympathy towards unions has improved or deteriorated over time - and where possible on making comparisons between Australia and overseas - to determine if sympathy towards unions is lower or higher in Australia than counterpart countries.

A feature that has set Australian industrial relations apart from those in most other industrialised nations has been the arbitration system. The origins of arbitration in Australia date to the industrial defeats of the 1890s as unions battled employers facing substantial pressure to reduce costs in the context of economic depression. Unemployed workers took the jobs of striking unionists and membership of unions had, after two decades of substantial expansion, declined dramatically. Unions sought legislative refuge from further employer onslaughts. In the 1890s and 1900s, tribunal-based arbitral systems or wages boards were introduced in the Australian colonies cum States and, in 1904, in the Australian Federal system (Hagan 1983; Macintyre 1982). Arbitration was founded on the utopian hope that it would bring an end to industrial conflict. Industrial action was illegal through most of the $20^{\text {th }}$ century - though for a considerable time until the mid 1980s the limitation on strikes had little practical effect on industrial behaviour. Only with the passage of the Industrial Relations Reform Act 1993 did strikes in support of a proposed agreement become legal in the federal jurisdiction. The federal tribunal was precluded from settling such disputes by arbitration. Broadly similar developments occurred across most State jurisdictions in the 1990s. 
Strikes, then, ran against the ideals of the arbitration system and, we might expect, against the norms of voters. We might also expect that consumers become annoyed with unions (and less sympathetic) when their purchasing or transport plans are disrupted by industrial action. Indeed, there is survey evidence that employees whose work is disrupted by industrial action also become annoyed with and less sympathetic to unions. In a 1990-91 survey of 942 employees in metropolitan Sydney establishments (SEMSE, see Peetz 1998), union sympathy amongst employees was lower in workplaces which, according to data from the 1990 Australian Workplace Industrial Relations Survey (AWIRS, see Callus et al 1991), had experienced disruption in production as a result of industrial action elsewhere. Interestingly, this relationship was only evident in workplaces which, themselves, had not experienced strike action in the previous year. Amongst workplaces which had not experienced a strike over the year preceding AWIRS, but which had experienced disruption due to industrial action elsewhere, 43 per cent of respondents in the employee survey were recorded as having anti-union sympathy; where there had been no disruption due to action elsewhere, anti-union sympathy was only 28 per cent. In workplaces which had themselves experienced strike action, disruption through industrial action elsewhere had no effect on union sympathy. In other words. industrial action appears to only have a negative impact on union sympathy amongst people who cannot empathise, through their own experience, with the situation facing strikers.

In sum, in light of the norms of arbitration, Australian unions could have difficulty from obtaining the sympathy of the general public if their behaviour is at odds with the norms of the legal system in place - that is, if unions engage in high levels of industrial disputation at times when it is expected that they should accept the decision of the independent arbitrator. 
People's direct experiences of the impact of industrial disputes (shortages of goods or transport) may make them feel more negative towards unions. This may be all the more so when they feel union behaviour goes against the norms of the industrial relations system. Any antagonism may be heightened by the role of the mass media, which have generally been considered to be antagonistic towards unions, particularly during industrial disputes (Windschuttle 1981). There is also evidence from Britain of an inverse relationship between changes in union sympathy and industrial conflict (Edwards \& Bain 1988, 1990). Consequently, disapproval of unions might be highest when industrial conflict is at its highest.

What, then, were the trends in industrial disputation in the post-war era? For the first five years, disputation was at high levels - averaging 1.7 million working days lost (WDL) per annum. This fell to a fairly consistent average of 1.0 million WDL during the 1950-56 period, and then an average of only 0.6 million over the 1957-67 period (Deery \& Plowman 1990:66). However, the wage determination system underwent a period of gradual decentralisation from 1967 to 1974, in no small part because the authority of the Australian Conciliation and Arbitration Commission with the union movement was eroded as a result of the Commission's decision in the Metal Trades Work Value case to increase award rates of pay, but stipulate that these increases be absorbed into overawards. Unions successfully resisted absorption and moved away from national wage determination to industry level negotiations. During the period from 1961 to 1967, some 85 per cent of the overall increase in award rates of pay was accounted for by national wage increases in basic wage, margins and total wage cases. This fell to 53 per cent in 1969-70, and by 1974-75 only 21 per cent of the increase in award wages was attributable to national wage cases (Hancock Committee 1985:44). Recorded industrial conflict rose, with 2.0 million working days lost in 1969, 3.1 million in 1971 and 6.2 million 
in 1974. Disputation eased in 1975 but still averaged 3.2 million working days lost per annum over the 1975-1981 period. Only with the introduction of the prices and incomes Accord from 1983 could a sustained reduction in industrial conflict be observed, with disputation averaging 1.2 million working days lost annually over the 1983-1996 period (ABS Cat No 6322.0). Multivariate studies have shown that the Accord was associated with a reduction in disputation well below that which would be predicted on the basis of trends in macroeconomic variables including unemployment (Beggs \& Chapman 1987a,b; Chapman \& Gruen 1990; Morris \& Wilson 1994, 1995). Initially, the decline in industrial disputation associated with the Accord in its centralised period was almost entirely a result of an 80 per cent decline in the number of working days lost due to disputes over wages. With the introduction of enterprise bargaining under the Accord, there was a further drop in all types of industrial dispute apart from 'other disputes' (this last result simply reflects the protests against the Victorian Government's industrial relations legislation in 1992). This suggests that there was a change in 'strike psychology' associated with the introduction of enterprise bargaining and of the right to strike, which clarified the role of industrial disputation in contrast with the ever ambiguous position under awards and arbitration. Notwithstanding the waterfront dispute (which did not appear in official statistics) disputation was lower still in the post-Accord period of the Howard government.

Overall, then, in the Australian context of a conflict between the taking of strike action and the norms of the arbitration system, we would expect that sympathy towards unions would be lower during and after the rise in disputation levels evident in the 1970s, and would improve during and perhaps after the Accord, but we could not prima facie predict the speed and durability with which public opinion changes in response to changes in disputation levels. In addition, the extent of these changes could depend on the type of measure being used. For 
example, during the Accord unions may have been seen as being more powerful (due to the close relationship with the ALP Government) but also more responsible. Measures of union sympathy that test the degree to which unions are seen as acting responsibly may therefore show a stronger improvement than those which test the degree to which they are seen as being too powerful.

A factor that may have had an important influence on attitudes to unions in the 1950s and 1960s was the communist/anti-communist fighting within the union movement, culminating in the split in the Australian Labor Party (ALP) and the formation of the Democratic Labor Party (DLP) in the mid 1950s (Rawson 101-123). The effect of this split was to cripple the ALP politically, largely preventing it from regaining office until 1972 federally, and until later in several States. Left- and right-wing unions battled for coverage of already unionised employees. As Rawson (1978:107) pointed out, in no other Western country except Italy and France did communists become so prominent in trade unions and in Australia, unlike those countries, unionism was the only sphere in which communists attained prominence. Consequently, anti-communism was intimately associated with anti-unionism in Australia in the 1950s and 1960s, particularly when anti-communist ideology was being propagated by conservative political parties and media. Only with the re-election of the Whitlam ALP Government in 1974, which also saw the demise of the DLP from the Senate, could anti-communism be said to have lost salience as a major feature of Australian polity. Even then, its effects on the union movement lingered for two more decades, with several unions associated with the DLP not reaffiliating with the ALP for some years. We might expect that the rhetoric and propaganda of anti-communism would damage sympathy towards unions and this would be most apparent in the 1950s and 1960s. On the other hand, the decline in industrial disputation between the early 1950s and the early 1960s might lead to an improvement in union sympathy during this period. The net impact of these two 
forces is not easy, prima facie, to predict.

One other issue that may need to be taken into account is the degree to which broader changes in society have made collectivist orientations more difficult. Assertions are commonly made (eg BCA 1989) that Australia is becoming a much more individualistic society and that, because of this, unionism is no longer relevant. Although these claims are often exaggerated (Frenkel \& Peetz 1990), there are some aspects of social change that may undermine union sympathy over the very long term. Changes in transportation, urbanization and technology make it less essential that people working together live near each other and so reduce the impetus for developing a sense of common community purpose at work. The growth of individualistic leisure pursuits such as television and computer games may have an effect. Business groups themselves seek more aggressively to promote individualism as an ideal ahead of collectivism (eg BCA 1989), because of a growth of anti-union ideology amongst employers and changes in the economic environment in which large firms operate and which make firms more resistant to unions (Coghill 1987). And the decline in union density itself may reduce union sympathy: there is a well-researched link between parental union membership and sympathy towards unionism (Van de Vall 1970; Gallie 1989; Hartley 1992) and so, over the long term, declining density amongst parents will of itself change the way in which socialisation occurs and lead to declining sympathy amongst a new cohort of voters.

Indeed, in relation to the question of how union sympathy has changed over time, we are also interested in what this implies about the reasons behind the decline in union density. Consequently, it is worth briefly describing trends in union density over the post war period. By the end of the second world war union density in Australia, bolstered by the arbitration system, stood at 54 per cent. It dipped slightly to 51 per cent, immediately after the war, then 
resumed an upwards path that had been underway since late in the Great Depression, peaking at 63 per cent in 1953 at the height of the Korean war boom. Thereafter union density declined gradually, to trough at 49 per cent in 1969 and 1970. It rose to 56 per cent by 1975 and remained within one or two percentage points of that, on the union census data, for several years. Since the mid 1980s, however, it has fallen substantially, and by 1999 little more than one in four employees belonged to a union in their main job. Some have claimed increased disillusionment of union members with their unions has been reflected in further declines in union membership (Moore 1999; Rawson 1983). If this is so, there should be a substantial decline recorded in union sympathy during the 1980s and 1990s.

\section{Changing union sympathy}

The major difficulty in investigating changes in union sympathy lies in the absence of a consistent series of data on union sympathy. However, there are a few questions which have been asked often enough in opinion polls to enable some trends to be examined. We consider data on seven issues, covering various periods since the 1940s.

The first of these issues concerns whether unions have been a good thing or not for the country. Results can be seen in Figure 1. These questions have been asked principally in opinion polls at various times over the past four decades. Despite some variation in wording, it seems that union sympathy as measured by these questions was substantially stable (though with some slight decline) between 1951 and 1966, but there was a more substantial shift against unions sometime between 1966 and 1974. After then there appears to have been some oscillation of responses to this question. By the end of the 1980s, responses to the question were only slightly worse for unions than they had been in 1974, but much worse than they had 
been in 1952. With the relatively small number of observations in 1992, the movement from 1990 to 1992 was not statistically significant. Not shown in the chart are several Newspoll surveys undertaken from 1996 and commissioned by the Labour Council of NSW, which sought people's attitudes on the converse proposition - whether Australia would be better off without unions. The proportion agreeing fell from 23 per cent in 1996 to 14 per cent in 2001 (Peetz 1998; Workers Online 2001), indicating an improvement in union sympathy.

\section{figure 1 about here}

Sources and data: See Appendix.

It is not clear, then, whether there was much movement during the Accord period on this indicator of union sympathy, which embodies views about unions' historical role. Responses to our second question, which have a more contemporary orientation, suggest that union sympathy may have increased during the Accord period (1983-1996). On various occasions from 1984 to 1995 the Australian Election Survey and National Social Science Survey asked respondents how good a job the trade unions were doing for the country. The proportion of respondents saying unions were doing a 'fairly good', 'very good' or 'excellent' job rose gradually from around 35 per cent to 50 per cent between the mid 1980s and the mid 1990s (Figure 2). ${ }^{\mathrm{i}}$

\section{figure 2 about here}

Sources and data: see Appendix. 
Our third set of questions tapping some aspect of union sympathy, and which is the only other one going back to mid century, concerns compulsory unionism. Polls taken in the early 1940s gave mixed results. Indeed, one survey showed support and opposition to compulsory unionism were evenly divided. During the 1950s opposition increased significantly (particularly after the ALP split, when fear of being forced to join a communist-led union may have been salient) and most polls taken from the 1960s onwards show a high level of opposition to compulsory unionism. There is little information on which to identify trends in the Accord period (Figure 3).

One general comment worth making, however, is that the high level of opposition recorded to compulsory unionism partly reflects the wording of the questions. For example, a 1959 poll showed a clear majority (63 per cent to 29 per cent) opposed to compulsory unionism - but it also showed a majority (54 per cent to 32 per cent) supporting the idea that if jobs become scarce...members of trade unions should...have first preference for jobs, over non-unionists'. Discrepancies of similar magnitude were found in other surveys around that time (APOP 1956, 1958b, 1959). ${ }^{\text {ii }}$ This is not, of course, to suggest that such a notion would still command majority support in current times.

\section{figure 3 about here}

Sources and data: See Appendix. 
A much larger number of observations (though over a shorter time) are available on our fourth set of questions, concerning whether unions have too much power. The data are presented in Figure 4.

As can be seen, there are several different ways in which the question has been asked. The most problematic distinction is between those questions which ask specifically about union power, and those which provide respondents with a list of several groups, and ask them to identify those groups which have too much (and not enough) power. The latter approach appears to produce lower and possibly more erratic numbers than the former approach (the same thing happens when you ask people what they think about the power of 'big business'), and the following interpretation takes this into account.

The data indicate a major increase between 1967 and 1976 in the proportion of people who considered that unions had too much power. Although some of this may have occurred in the 1967-1971 period, it seems that the greatest change took place between 1971 and 1974. This pattern is consistent with the data on whether unions are a good thing, shown in Figure 1. This deterioration in public support for unions coincided with a marked escalation of industrial disputation to a post-war peak in 1974. 


\section{Figure 4: Unions have too much power}

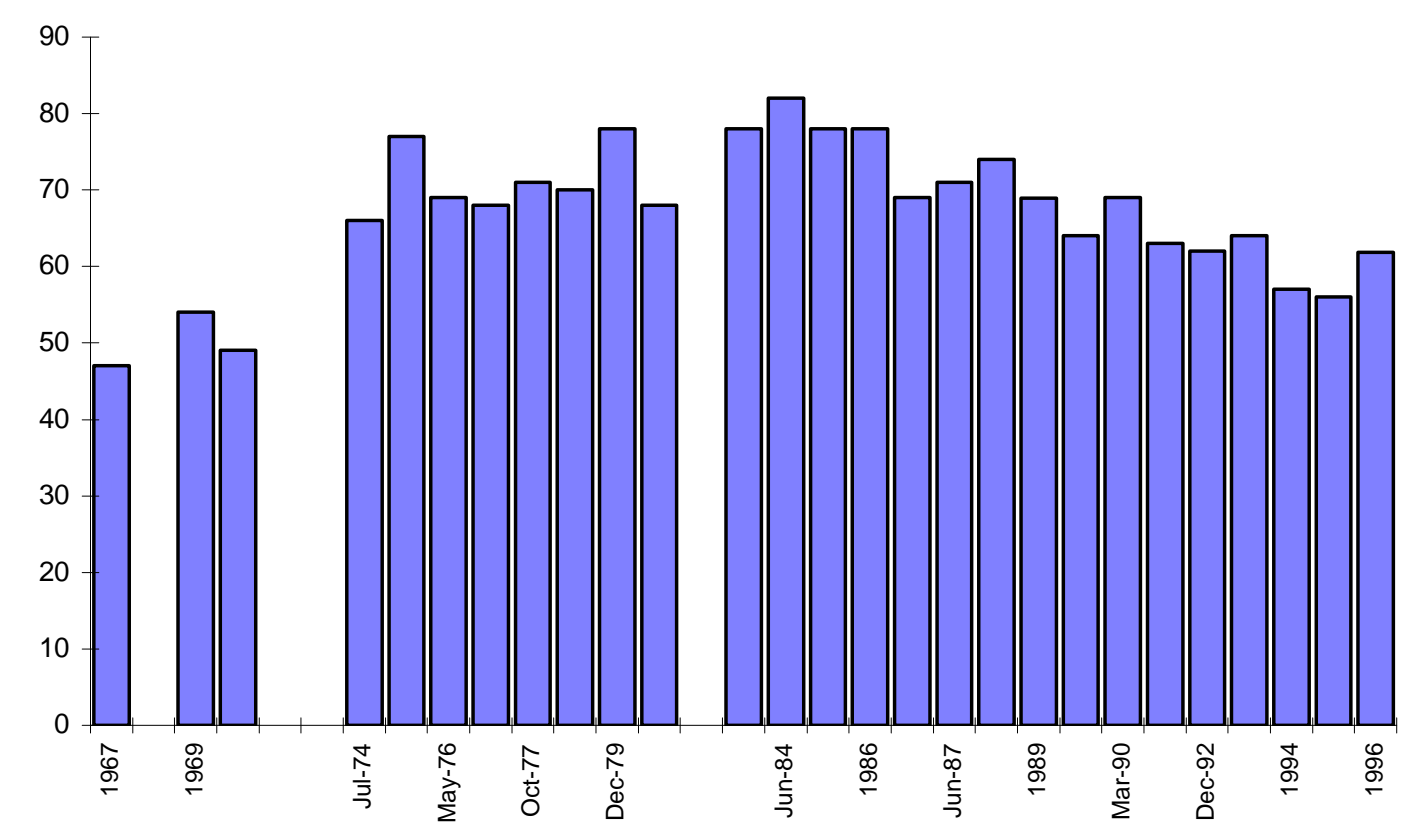

figure 4 about here

Through the latter part of the 1970s attitudes towards union power remained fairly stable at this new, higher level of antagonism. But in 1979 there appeared to be another rise in the extent of the belief that unions had too much power. This was probably associated with an increase in public perceptions of industrial disputation. (Between March 1978 and September 1978, the proportion of Australians who thought it more likely that industrial conflict would increase rather than decrease over the coming months rose from 51 per cent to 82 per cent, and the 3.9 million working days lost in 1979 were 82 per cent higher than in 1978 and represented the second highest number of working days lost recorded in the preceding two decades (ABS Cat No 6321.0).) Soutar, Savery and Dufty (1985) found a similar pattern of 
deteriorating attitudes to unions in 1979 in their own survey of Perth residents and attributed it to an increase in industrial conflict (see also NSSS 1989). After a short fall, the proportion of Australians thinking unions had too much power remained at nearly 80 per cent until the Accord came into place.

A negative relationship between union sympathy and industrial conflict would suggest that the reduction in industrial conflict associated with the Accord should have been accompanied by an improvement in pro-union sympathy. Initially, however, this did not occur: the belief that unions had too much power remained at its new high level of nearly 80 per cent until well into the Accord period. The Accord was widely and correctly seen by commentators as representing an increase in union power at the peak level (Carney 1988), and presumably this perception was partly shared by the wider public. If union power is seen to be increasing, then the number of people who say that unions have too much power would also increase. ${ }^{\text {ii }}$

After three or four years of the Accord, the belief that unions had too much power started to decline. It is unclear whether this just reflected public acceptance that industrial disputation had undergone a more permanent, downward shift, or also reflected a perception of declining union power. But by the mid 1990s the state of union sympathy on this measure was better than it had been since the early 1970s. In 1994 and 1995 the proportion of people claiming unions had too much power fell below 60 per cent. It rose slightly in the 1996 election period, during which the Secretary of the ACTU made comments implying industrial turmoil under a future Coalition Government. Not shown in this chart are subsequent declines in the proportions of adults who both 'clearly agree' that unions have too much power and 'clearly disagree' that strong unions are essential to protect Australians' wages, in an annual survey by Quantum, from 36\% in 1997 to 33\% in 1999 and 28\% in 2001 (AustraliaSCAN 2001). ${ }^{\text {iv }}$ 
However, the decline in anti-union sentiment on this index was not matched by an equal improvement in pro-union sentiment. ${ }^{\mathrm{v}}$

The overall pattern on union power was consistent with the pattern shown regarding some other aspects of union sympathy in Figure 1, where we saw that the belief that unions were a good thing was almost as prevalent in 1990 as it had been in 1974, and Figure 2, which showed an improvement in public attitudes on what sort of job unions were doing for the country during the Accord period. However, by reference to union power, union sympathy was still not as positive in the late 1990s as it had been in the mid 1960s.

Our fifth set of questions concern people’s reported general sympathies for or against strikers. Antagonism towards strikers rose appreciably between 1969 and 1979, consistent with the pattern in the 'too much power' series (Figure 5). By the mid 1980s, however, sympathy towards strikers was at, or better than, the levels of the later 1960s. While sympathy towards strikers was better during the Accord period than in 1979, the data are too erratic to tell us whether there was a trend decline during the course of the Accord period. Still, even at the best of times, the number of people whose sympathies were generally against strikers easily outnumbered those whose sympathies were generally for strikers.

\section{figure 5 about here}

Sources and data: see Appendix. 
Figure 6 shows us responses to the proposition that there should be stricter laws to regulate trade unions. Again, each observation shows a majority in favour of stricter laws. Nonetheless, the data clearly show a reduction in the proportion of people calling for stricter laws during the Accord decade from 1986 to 1996 - a trend that continued even after passage of the Industrial Relations Reform Act 1993 which was seen as pro-union by some commentators (eg Sloan 1994; Hamilton 1994).

\section{figure 6 about here}

Source and data: see Appendix.

Finally, there is one series which has been running almost annually and quite consistently since the mid 1970s: a Morgan Poll question on the perceived degree of integrity and honesty of a number of occupations including "union leaders". When commenced in 1976, the question covered 14 occupations; by 2000 this had doubled to 28. It is not as useful a question as the others that have been discussed above (it concerns union leaders, not unions themselves, and does not describe the core activity of unions) but is worth mentioning because of its regularity and consistency. Results are shown in Figure 7. Typically, this has not been a measure by which Australian union leaders perform well: from the time the series started until the mid 1980s, union leaders rated second lowest (above 'car salesmen') on the ethics and honesty scale, with the lowest scores occurring in the 1984-86 period, when unions were first seen as exercising their political muscles under the Accord. Since then, however, attitudes towards union leaders have improved. During 1997-2000 the incidence of 'high' ratings for ethics and honesty was double that in the mid 1980s, and union leaders had 
climbed past a number of occupations to be rated equal $21^{\text {st }}$ of 28 occupations. This is consistent with the other indicators pointing towards improving union sympathy over the 1990s.

\section{Figure 7}

\section{Union leaders: high ratings for ethics and honesty}

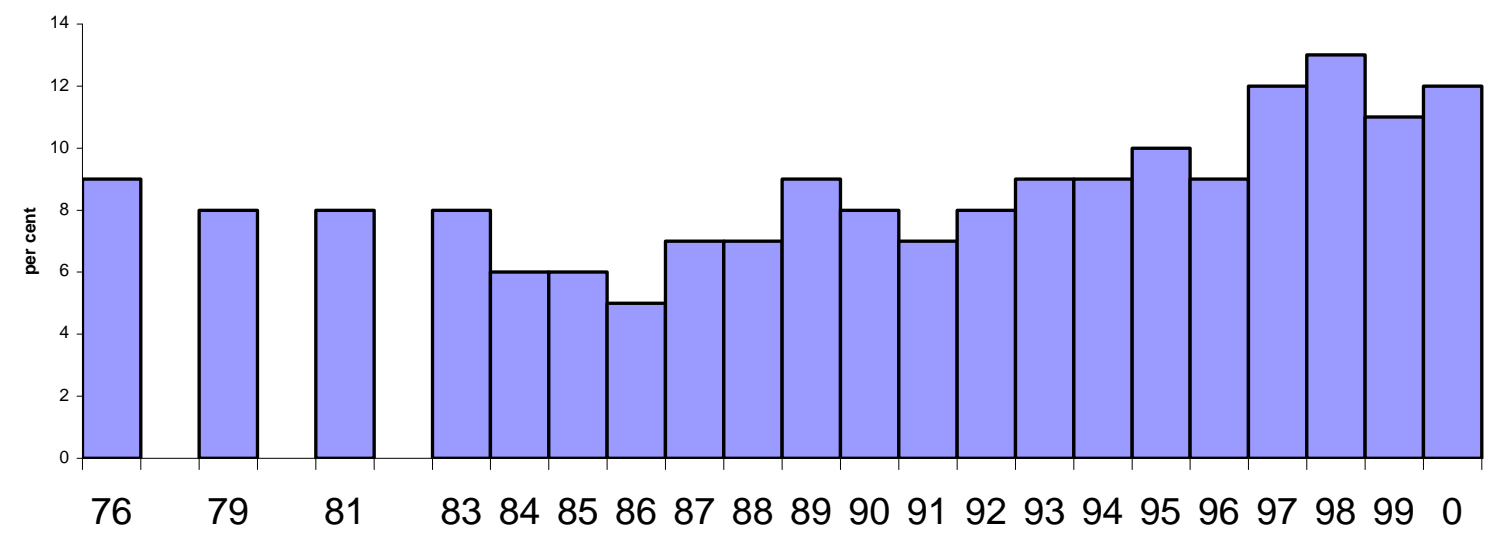

figure 7 about here

Sources and data: see Appendix.

The overall trend that emerges from these various aspects of union sympathy appears to be that: union sympathy slowly declined between the 1940s and the 1960s; it deteriorated sharply during the early 1970s; and it recovered slowly, after initially dipping, under the Accord. Yet during the last period, union density fell, from nearly 50 per cent to barely 30 per cent; the decline in union density could not be explained by declining union sympathy. 


\section{Union sympathy in the international context}

Cross-national variations in union sympathy are interesting in their own right, because they reveal something about the differing states of political consciousness in different countries. But are such patterns significant for unions themselves? International differences in union density are not explained by international variations in union sympathy (Chaison \& Rose 1991). Nonetheless, the comparative state of union sympathy might indicate something about the vulnerability or otherwise of Australian unions to changes in the institutional, economic or political environment. At the start of the 1990s slightly over one half of union members were subject to compulsory union membership (Peetz 1998). The reduction or removal of compulsion - be it through legislative change, management strategy or structural change in the labour market - might have a more constrained impact if Australian employees had a strong ideological attachment to unions. But if the ideological motivation for membership is weak, unions' membership would be more sensitive to changes in compulsion, irrespective of whether or not ideological motivations played any significant role in the typical decision for union exit.

Cross-national data are very limited, but what is shown by those which do exist? An international social survey in 1986-87 indicated that, when 78 per cent of Australians took the view that unions had too much power, similar views were held by only 60 to 65 per cent of Britons, Americans and Italians and less than 40 per cent of Austrians and Germans (NSSS 1989). Even though identical questions were used, these data have to be interpreted cautiously, as different answers reflect particular circumstances. Still, in 1990, while 69 per cent of Australians were telling the NSSS that unions had too much power, only 47 per cent of Italians and Americans, 36 to 38 per cent of Britons, Norwegians and Israelis, 27 per cent 
of Germans, and 18 per cent of Hungarians, were expressing similar attitudes (Blanchflower and Freeman 1994:15). Other sources have shown comparisons that put Australian unions in an equally gloomy relative position: a US figure of only 37 per cent by 1988 (Mayer 1992:97), British figures of 36 to 40 per cent by 1987 to 1989 (Marsh 1990; Millward 1990), and a New Zealand figure of 48 per cent in 1988 (Insight 1988). Perhaps Australian unions were more likely than British, American and New Zealand unions to be perceived as being too powerful because they really were more powerful (a debatable proposition). But this would not explain the poor perception of Australian unions when compared with those in Austria, Norway and Germany where union density and, an arguable case can be made, union strength were greater than in Australia.

On other aspects of union sympathy, where data are readily available, Australian unions also perform worse than their overseas counterparts. The four Australian polls taken from 1987 onwards (Figure 1) showed an average of 61 per cent agreement that Australian unions have been a good thing for Australia. Two British polls over that period cited by Marsh (1990) have an average estimate of over 69 per cent. A small amount of workplace-level data collected for case studies showed similar patterns. ${ }^{\mathrm{vi}}$ Yet it appeared that, in the early 1950s, Australian unions were better regarded than their British counterparts. The estimates of 80 per cent and 75 per cent agreement that unions are a good thing, noted in the 1951 and 1966 APOP polls respectively (Figure 1), compared with estimates of 67 per cent and 63 per cent in Britain in 1955 and 1966 (Marsh 1990:59; Webb \& Wybrow 1981:78).

Australians have generally (though not always) been recorded as being unsympathetic towards strikers (see Figure 5; also APOP 1985a; Courier-Mail 1985; McNair 1988; APOP 1979b). In the late 1980s, New Zealanders were more sympathetic to strikers than to 
employers by a ratio of about 3:2. In Australia, those unsympathetic to strikers outnumbered those sympathetic by a ratio of at least 3:1, though by the mid 1980s it was down to about 2:1 (Insight 1988; NSSS 1987,1988, 1994,1995; McAlister \& Mughan 1987).

Why do Australian unions appear to have such a weak ideological foundation amongst employees and the wider community? One real possibility is that the Australian union movement lacks legitimacy as a result of its use of the strike weapon in the institutional context of Australia. The arbitration system has consistently held wide public support (APOP 1946, 1955, 1970a, 1979a, 1984b, 1986a; McNair 1988). Arbitration has been recorded as being of greater importance to Australians than the right to strike (APOP 1948, 1949, 1960, 1962b, Morgan 1977) and polls have generally shown support for the use of sanctions against unions that breach directions of industrial tribunals (eg APOP 1985a). Indications are that, at least in relation to workers not in essential services, Australians accept a principle of a right to strike (eg APOP 1971a, Morgan 1992a). Perhaps, however, when arbitration is available they have not recognised the legitimacy of the strike weapon in the same way in which people have accepted it in countries operating under purer collective bargaining frameworks.

These comparative data do not help explain the level of union density in Australia when compared with other countries. But they suggest that Australian unions may be more vulnerable than many of their counterparts overseas to the weakening of union security provisions, as has occurred since the late 1980s throughout Australia, to the point where union preference clauses and compulsory unionism are illegal in most situations.

\section{Conclusion}


Union sympathy is influenced by people's direct experiences of union membership, their direct and indirect experiences of industrial conflict, mediated by the effects of an anti-union media, socialisation by their parents and peers, amongst others, regarding unions, the degree to which union behaviour is seen as being consistent or inconsistent with people's own values and norms, and the general climate of debate, opinion and propaganda on the role of unions. Changes in union sympathy can be influenced by changes in the level of industrial disputation (which can affect not only the inconvenience people feel from union activity but also the degree to which unions are seen as acting inconsistently with social norms), changes in the nature of public debate and propaganda (for example, in the Australian case, on anticommunism), and changes in socialisation arising from broader social forces.

Union sympathy slowly declined between the 1940s and the 1960s; it deteriorated sharply during the early 1970s; and it recovered slowly under the Accord. The deterioration after the 1940s might be attributable to anti-communism and its association with anti-unionism during the 1950s and 1960s, though the data do not permit us to be definitive on this point. The forces that were depressing union sympathy in this period more than offset any upward impacts that might have arisen from the decline in industrial disputation between the late 1940s and the early to mid 1960s. The deterioration during the 1970s was associated with a significant rise in industrial conflict. The improvement in sympathy during the 1980s and 1990s was probably linked to the Accord-related fall in the level of industrial disputation and to the level of 'responsibility' the union movement was seen, in that context, to be exercising, though initially at least this appeared to be tempered by concern with the degree of influence unions were exerting on public policy. Measures of union sympathy that tapped the degree to which unions were seen as being too powerful improved later, and more slowly, than other indicators of union sympathy. Hence the improvement in union sympathy was slow to take 
place, compared to the speed and magnitude by which industrial disputation fell. This may also reflect lags in the recognition of a decline in disputation and/or 'stickiness' in adverse opinions (an aggravation may quickly generate adverse opinions, but those adverse opinions may take considerable time to dissipate after the initial aggravation has long eased).

Despite industrial disputation in the late 1990s being below the levels achieved in any other decade since the war, it nonetheless appears that union sympathy in the 1990s was weaker than it was in the 1940s. Some sort of structural shift appears to have occurred, over which the other trends mentioned above have been laid. The data here are not strong enough to show that this reflects an underlying weakening of the forces that promote socialisation to collectivist orientations, but they are suggestive that such might have occurred. With a smaller proportion of workers belonging to trade unions now than at any time in the last ninety years, and with overall sympathy towards unions lower than in the 1940s and 1950s, parental socialisation favouring collectivism will also be weaker than in the past, putting ongoing downwards pressure on union sympathy in the future.

Whatever has happened to collectivist orientations, the pattern of union sympathy over the past two decades demonstrates that the decline in union density between the early 1980s and the late 1990s cannot be directly attributed to a shift in union sympathy during this period. While sympathy rose, union density fell, principally - as other research has shown (Peetz 1998) - because of increasing employer and state resistance to unions, most clearly manifested in the collapse of compulsory unionism, structural changes in the labour market, and the weakness of workplace unionism. By contrast, sympathy and density both fell gradually during the 1950s and 1960s, and both could plausibly be linked to the effects of anticommunism. Improvements in union sympathy over the past two decades may make it easier 
for unions to increase membership but this may not be sufficient to offset the effect of these institutional and structural forces working in the opposite direction.

Of course, it must be acknowledged that Australian unions were starting from what appeared to be, by international standards, a low base in the early 1980s and have yet to recover properly from it. Cross national data are not robust enough to enable us to definitively show why Australian unions have been so unpopular. One plausible factor was anti-communism, given the particularly prominent and concentrated role played by communist leaders in the union movement in Australia in the 1950s, and the intimate association of anti-communism with anti-unionism in Australia, particularly when anti-communist ideology was being propagated by conservative political parties and media.

More significantly, the evidence points to there being a negative relationship between union sympathy and levels of industrial conflict, and Australia is often cited as being a relatively strike-prone nation. This relative strike-proneness is easily overstated; for example, in the decade from 1983, Australia had fewer working days lost per thousand employees than the UK (ABS Cat No 6322.0; Department of Labour 1993). What really distinguishes strikes in Australia from those in the UK and most other countries is that in Australia they have been, in the context of the tribunal-based award system, illegitimate - at least until 1994. It is difficult to avoid the conclusion that no small part of the low level of sympathy towards Australian unions is the result of their usage of a tool which has been seen as illegitimate in the eyes many of the public, who would have preferred that unions relied on arbitration to secure their goals. Unions in many other countries have simply not faced such a deep problem of legitimacy regarding their use of a key tactical weapon. 
Arbitration has hampered union sympathy in another way. While making use of strikes in strategic sites, Australian unions have nonetheless relied heavily upon arbitration to achieve their goals across the rest of their areas of coverage, at the expense of more effective development of workplace level union organisation (Peetz 1998). An argument that has been used in relation to the Accord (Kenyon \& Lewis 1992) but which can be generalised to most of the last century for the majority of award-covered employees, is that unions secured substantial gains but for many people did not receive the 'credit' for these gains. By not engaging members in the achievement of gains, unions failed to develop strong union consciousness. Thus arbitration hampered the development of union sympathy against both non-members and members.

It is important to emphasise, though, that it does not follow from these data that unions can reverse their decline in membership by striking less often. For one thing, union sympathy is only one influence on union membership, it is clearly not the main factor driving changes in membership, and 'successful' industrial conflicts can directly increase union membership (Peetz 1996; Western 1993a), much more quickly than any associated decline in union sympathy might affect membership. For another, not all industrial disputes attract the ire of the public. The waterfront dispute of 1998, the dispute with the highest profile of any during the 1990s, saw public opinion evenly divided between support for the union and support for the employer and the government (Morgan 2001), and appeared to be associated with a fall in government support $^{\mathrm{vii}}$ - precisely because in this dispute it was the government and the employer that were seen by many people to have acted against the norms of industrial relations by engineering the sacking and replacement of a unionised workforce. In that dispute the union gave high priority to ensuring its actions remained legitimate in the eyes of the courts and the public. Moreover, the ire of the public is likely to be attracted less and 
less frequently by industrial disputes: arbitration now is but a shadow of its former self, and the legitimacy of strikes is less open to moral challenge. Since the passage of the Industrial Relations Reform Act 1993 Australia has adopted a legislative bargaining regime that is closer to those applying in other countries. Indeed, it would be tempting to conclude that this in itself may have assisted union sympathy after 1994, though we should be skeptical that the contribution would be large at first, as public understanding and appreciation of the ramifications of these policy changes is likely to take considerable time. Perhaps over the long term, levels of union sympathy in Australia and elsewhere might converge. One way or another, though, the fate of Australian unions will be determined long before that happens. 


\section{APPENDIX}

\section{Figure 1 - Unions have been a good thing for Australia}

$\begin{array}{cccl}\text { date } & \% & \text { N } & \text { reference } \\ \text { Feb-51 } & 80 & 1700 & \text { APOP (1951) } \\ \text { Nov-66 } & 75 & 1787 & \text { APOP (1966) } \\ \text { Aug-74 } & 62 & 2270 & \text { Morgan (1974) } \\ 1976 & 69 & 4046 & \text { Rawson (1976) } \\ \text { Feb-87 } & 60 & (\text { na) } & \text { Morgan (1992) } \\ \text { Sep-89 } & 67 & (\text { na) } & \text { Morgan (1992) } \\ 1990 & 60 & 1000 & \text { Rawson (1992) } \\ \text { Dec-92 } & 57 & 577 & \text { Morgan (1992) }\end{array}$

Questions: 'Looking back over the history of trade unions in Australia, do you think that the unions have been a good thing for Australia or not' (APOP 1951;

Morgan 1992a); 'Speaking generally, do you think that unions are a good thing or a bad thing' (APOP 1966);

'Do you think that, on the whole, unions have been a good thing for Australia or not' (Morgan 1974; Rawson 1976,1992).

Figures in \% column indicate \% saying 'good thing'.

Figure 2 - Unions are doing a good job for the country

$\begin{array}{cccl}\text { date } & \% & \text { N } & \text { reference } \\ 1984 & 36 & 2935 & \text { NSSS 1984 } \\ 1986 & 35 & 1484 & \text { NSSS 1986-87 } \\ 1988 & 41 & 1632 & \text { NSSS 1987-88 } \\ 1989 & 43 & 5858 & \text { NSSS 1989-90 } \\ 1994 & 47 & 1503 & \text { ISSS 1994 } \\ 1995 & 50 & 2438 & \text { ISSS 1995 }\end{array}$

Question: 'In general, how good a job would you say the trade unions are doing for the country as a whole?'

Figures in \% column indicate \% saying 'fairly good', 'very good' or 'excellent'.

\section{Figure 3 - Attitudes to Compulsory unionism}

\begin{tabular}{|c|c|c|c|}
\hline $\begin{array}{l}\text { Source: } \\
\text { Date }\end{array}$ & $\begin{array}{cc}\text { Vol } & \text { Comp } \\
\% & \%\end{array}$ & reference & Date \\
\hline
\end{tabular}




\begin{tabular}{lllll|lllll}
1942 & 36 & 52 & (na) & APOP (1942) & 1974 & 21 & 73 & 2270 & Morgan (1974) \\
1943 & 41 & 41 & (na) & APOP (1943a) & 1976 & 42 & 56 & 1969 & Age Poll (1976) \\
1943 & 26 & 64 & 2000 & APOP(1943b) & 1976 & 22 & 68 & (na) & Morgan (1978) \\
1953 & 38 & 50 & (na) & APOP (1953) & 1978 & 21 & 73 & 2214 & Morgan (1978) \\
1956 & 26 & 69 & 2000 & APOP (1956) & 1978 & 31 & 66 & 1969 & APOP (1978) \\
1959 & 29 & 63 & 1800 & APOP (1959) & 1982 & 25 & 73 & 2087 & APOP (1982) \\
1966 & 30 & 63 & 1787 & APOP (1966) & 1983 & 16 & 78 & 942 & Social Impacts/Morgan(1983 \\
1971 & 25 & 68 & 2000 & APOP (1971b) & 1987 & 22 & 73 & 1150 & Newspoll (1987)
\end{tabular}

Questions: 'Do you favour, or oppose, compulsory unionism for all employees?' (APOP 1943a); 'Should membership of trade unions be voluntary or compulsory?' (APOP 1942, 1943b, 1966); Should all wage and salary earners, except executives, be compelled to join trade unions? (APOP 1953) 'Should membership of trade unions, by all wage earners, except foremen and managers, be voluntary or compulsory?' (APOP 1971b); 'Should it be compulsory or not compulsory for workers in certain industries such as transport to join a trade union?' (APOP 1978, 1982); Should the items in the list definitely be compulsory, probably be compulsory, probably not be compulsory or definitely not be compulsory? (Age Poll 1976) 'Are you in favour or against compulsory unionism in Australia?' (Newspoll 1987) Figures in 'Vol' column indicate \% saying membership should be voluntary, not compulsory or disagreeing that it should be compulsory.

Figure 4 - Unions have too much power

\begin{tabular}{|c|c|c|c|c|c|c|c|}
\hline Date & $\%$ & $(\mathrm{~N})$ & reference & Date & $\%$ & $(\mathrm{~N})$ & reference \\
\hline 1967 & 47 & 2054 & Aitkin (1977) & 1986 & 78 & 1528 & NSSS (1989) \\
\hline 1969 & 54 & 1873 & Aitkin (1977) & 1987 & 69 & na & Morgan (1992a) \\
\hline 1971 & 49 & $(1000)(\dagger)$ & Age (1971) & 1987 & 71 & 1825 & $\begin{array}{l}\text { McAllister \& } \\
\text { Mughan (1987) }\end{array}$ \\
\hline 1974 & 66 & 2000 & Age (1974) & 1987 & 74 & 1574 & NSSS (1989) \\
\hline 1975 & 77 & 1997 & APOP (1975) & 1989 & 64 & na & Morgan (1992a) \\
\hline 1976 & 69 & 4046 & $\begin{array}{l}\text { Morgan } \\
\text { (1976b) }\end{array}$ & 1990 & 69 & 2037 & McAllister et al (1990) \\
\hline 1976 & 68 & 1990 & APOP (1976) & 1992 & 63 & 1000 & Saulwick (1992) \\
\hline 1977 & 71 & $(2042)(\ddagger)$ & APOP (1977) & 1992 & 62 & 577 & Morgan (1992) \\
\hline 1978 & 70 & 1969 & APOP (1979a) & 1993 & 64 & 3023 & Jones et al (1993) \\
\hline 1979 & 78 & 2016 & APAS (1979) & 1994 & 57 & 1503 & NSSS94 \\
\hline 1980 & 68 & 1820 & Age (1980) & 1995 & 56 & 2438 & NSSS95 \\
\hline 1983 & 78 & $(868)(\S)$ & $\begin{array}{l}\text { McNair Beed } \\
\text { (1983) }\end{array}$ & 1996 & 62 & 1737 & Jones et al (1996) \\
\hline 1986 & 78 & 1150 & $\begin{array}{l}\text { Newspoll } \\
\text { (1986) }\end{array}$ & & & & \\
\hline
\end{tabular}

Figures in cells indicate \% saying unions have too much power.

Questions: 'Do you think that trade unions in Australia are too powerful, or not powerful enough, or do they have about the right

amount of power?' (APOP 1977, 1979a) ; 'Do you think unions in Australia have too 
much power, about the right amount, or too little power?' (Newspoll 1986); 'Do you think that trade unions in this country have too much power or not too much power?'

(McAllister \& Mughan 1987); 'Do you think that trade unions in this country have too much power or too little power?' (NSSS

1989); 'Trade unions have too much power' (strongly

agree/agree/neither/disagree/disagree strongly) (Jones et al 1993); 'The trade

unions in this country have too much power' (strongly agree/agree/

neither/disagree/disagree strongly) (McAllister et al 1990);

'Which of these groups would you say have too much power?' (Age 1971, 1974, 1980)

Figure 5 - Generally against strikers

$\begin{array}{llrl}\text { Date } & \% & \text { N } & \text { reference } \\ 1967 & 38 & 2054 & \text { Aitkin (1977) } \\ 1969 & 41 & 1873 & \text { Aitkin (1977) } \\ 1979 & 49 & 2016 & \text { APAS (1979) } \\ 1986 & 37 & 1496 & \text { NSSS (1986-87) } \\ 1987 & 31 & 1816 & \text { McAllister \& Mughan (1987) } \\ 1988 & 39 & 1646 & \text { NSSS (1987-88) } \\ 1989 & 30 & 5881 & \text { NSSS (1989-90) } \\ 1990 & 30 & 2014 & \text { McAllister et al } \\ & & & \text { (1990) } \\ 1993 & 30 & 2964 & \text { Jones et al (1993) } \\ 1994 & 38 & 1503 & \text { NSSS (1994) } \\ 1995 & 32 & 2438 & \text { NSSS (1995) }\end{array}$

Question: 'When you hear of a strike, are your sympathies generally for or against the strikers?' with responses: almost

always for/usually for/sometimes for (and sometimes against) /usually against/almost always against (NSSS 1986-87, 1987-88, 1989-90); usually for/sometimes for and sometimes against /usually against (AES 1993); generally for/it depends/generally against (AES 1987, 1990).

AES 1984, which did not have a neutral category, has been excluded from this analysis. Figures in \% column indicate \% saying 'generally against', 'usually against' or 'almost always against'.

Figure 6 - Should be stricter laws on unions

Sources: 


$\begin{array}{rrrl}\text { Date } & \% & \text { N } & \text { Reference } \\ 1986 & 81 & 1483 & \text { NSSS (1986-87) } \\ 1987 & 74 & 1776 & \text { McAllister \& Mughan (1987) } \\ 1988 & 81 & 1634 & \text { NSSS (1988-89) } \\ 1990 & 68 & 1995 & \begin{array}{l}\text { McAllister et al } \\ (1990)\end{array} \\ 1993 & 64 & 2925 & \text { Jones et al (1993) } \\ 1996 & 59 & 1737 & \text { Jones et al (1996) }\end{array}$

Question: 'There should be stricter laws to regulate the activities of trade unions' (AES 1990, 1993, 1996); 'Do you think the government should introduce stricter laws to regulate trade unions?' (NSSS 1986-87, 1987-88).

Figures in \% column indicate \% saying there 'definitely' or 'probably' should be stricter laws, or who 'agree' or 'strongly agree' with the statement.

Figure 7 - Union leaders: high ratings for ethics and honesty

$\begin{array}{llllll}\text { year } & \% & \text { year } & \% & \text { year } & \% \\ 1976 & 9 & 1987 & 7 & 1994 & 9 \\ 1979 & 8 & 1988 & 7 & 1995 & 10 \\ 1981 & 8 & 1989 & 9 & 1996 & 9 \\ 1983 & 8 & 1990 & 8 & 1997 & 12 \\ 1984 & 6 & 1991 & 7 & 1998 & 13 \\ 1985 & 6 & 1992 & 8 & 1999 & 11 \\ 1986 & 5 & 1993 & 9 & 2000 & 12\end{array}$

Source: Morgan (2000)

$\mathrm{N}$ : over 2000 in 1970s and 1980s, over 1000 in 1990s, 1070 in 2000.

Question: "Next, about different occupations. As I say different occupations, would you please say from what you know or have heard - which line best describes how you, yourself, would rate or score people in various occupations for honesty and ethical standards...How would you rate or score union leaders for honesty and ethical standards? (Very high, high, average, low, very low)” 


\section{REFERENCES}

Age Poll. 1971. 'Villains in the Power Game', Age, 25 March.

------ 1974. 'Unions Too Powerful, Say Voters', Age, 12 August.

------ 1976. 'Breath Test Approved', Age, 17 August.

1980. ‘Unions Judged Too Powerful'. Age. 23 June.

Aitkin, D. 1977. Stability and Change in Australian Politics. ANU Press. Canberra. 1st edn.

Albig, W. 1956. Modern Public Opinion. McGraw-Hill. New York.

ABS (Australian Bureau of Statistics). various years. Industrial Disputes, Australia, Catalogue No. 6322.0. Canberra.

Australian Political Attitudes Survey. 1979. frequencies code book and computer file, School of History, Politics and Philosophy, Macquarie University. Sydney.

APOP (Australian Public Opinion Polls). 1942. 'Public’s Attitude to Enforced Unionism'. 63. July.

1943a. ‘Opinion Divided on Enforced Unionism’. 107. February. 
1943b. 'Public Opposed to Compulsory Unionism'. 143. August.

1946. ‘Arbitration Court as Wage-Fixer’. 339. April-May.

1948. 'No Arbitration While Men are on Strike’. 487. February-March.

1949. 'Public Puts Arbitration Before Right to Strike’. 638. November-December.

1951. 'Trade Unions Have Done Good Work'. 761. February.

1953. ‘Compulsory Unionism Not Too Popular’. 949. August.

1955. 'Leave Hours, Wages to the Court'. 1131. November-December.

------ 1956. 'Preference for Voluntary Unions’. 1198. September.

- 1958a. 'Unions Entitled to Strike’. 1313. May.

1958b. Australian Gallup Poll, November 12.

http://ssda.anu.edu.au/SSDA/POLLS/D0179.html

1959. 'Preference for Voluntary Unions’. 1369. December.

1960. ‘Arbitration More Value than Strikes’. 1478. June-August 1960. 
1962. 'Court Better than Strikes'. 1640. November-December.

1966. ‘Unions Approved if Voluntary’ 1952. November.

- 1970. ‘Fix Wages by Arbitration’. 2172. January-March.

1971a. 'The Right to Strike Approved by 55\%’. 2268. June.

1971b. 'Forced Unionism Opposed’. Advertiser. 17 August.

1975. 'Trade Union Officials Have Too Much Power and Influence’. Poll No 06/9/75.

10 October.

1976. ‘Unions Should Not Call Political Strikes’. Poll No 01/7/76. 17 July.

1977. ‘Trade Unions Too Powerful - Gallup’. Poll No 04/10/77. 24 October.

1978. ‘Union Membership Should Not be Compulsory’. Poll No 05/11/78. 1 January.

1979a. 'Wage Indexation System Should be Modified'. Poll No 02/07/79. 1 August.

1979b. 'Most Australians Out of Sympathy with Recent Strikes’. Poll No 01/7/79.

1979c. ‘Union Membership Should Not be Compulsory’. Poll No 05/11/78. 1 January. 
1979d. 'Public Expects Increasing Unemployment, Inflation, Strikes’. Poll No 04/3/79.

5 April.

1982. ‘73 per cent say “No” to Compulsory Unionism’. Poll No 04/6/82. 30 June.

1984a. 'Most Concern About Unemployment and Inflation, Says Poll’. Poll No 06/3/84.

30 March.

1984b. 'Wage System gets a Strong "Yes"'. Poll No 04/11/84. November.

1985a. 'Penalise Unions that Defy Arbitration Directions’. Poll No 04/2/85. 26 February

(also in Advertiser. 28 February).

1985b. 'Most are Not Sympathetic with Striking Doctors, Power Workers, etc'. Poll No 03/5/85. 23 May.

- 1986a. ‘Conflicting Views on Deregulation and Privatisation'. Gallup Poll No 03/12/85.

2 January.

------ 1986b. 'Nurses' Right to Strike’. Poll No 01/12/86. 23 December.

AustraliaSCAN (2001) '2001: A Social Odyssey', notes, Quantum Market Research, Melbourne, and email communication with D Chalke, June 2001. 
Beggs, J J \& Chapman, B J (1987a) 'An Empirical Analysis of Australian Strike Activity:

Estimating the Industrial Relations Effect of the First Three Years of the Prices and Incomes Accord', Economic Record, March, 46-60.

------ 1987. 'Australian Strike Activity in an International Context'. Journal of Industrial Relations. 29(2). June, 137-49.

Bogart, L. 1977. Silent Politics: Polls and the Awareness of Public Opinion. Wiley. New York.

BCA (Business Council of Australia). 1989. Enterprise-Based Bargaining Units: A Better Way of Working. Report by the Industrial Relations Study Commission. BCA, Melbourne.

Blanchflower, D, \& Freeman, R. 'The Legacy of Communist Labor Relations', NBER Working Paper Series, 4740, National Bureau of Economic Research, May.

Callus, R, Morehead, A, Cully, M, \& Buchanan, J. 1991. Industrial Relations at Work. AGPS. Canberra.

Carney, S. 1988. Australia in Accord: Politics and Industrial Relations Under the Hawke Government. Sun. Melbourne.

Chaison, G N \& Rose, J B. 1991. 'The Macrodeterminants of Union Growth and Decline’ in G Strauss, G D Gallagher \& J Fiorito (eds), The State of the Unions. Industrial Relations Research Association, Madison WI. 3-46. 
Childs, H.L. 1964. Public Opinion: Nature, Formation and Role. D Van Nostrad Co. Princeton, NJ.

Chapman, B J \& Gruen, F. 1990. 'An Analysis of the Australian Incomes Policy: The Prices and Incomes Accord’. In C. de Neubourg (ed.) The Art of Full Employment. Elsevier/North Holland. Amsterdam.

Coghill, K. (ed). 1987. The New Right’s Australian Fantasy. Penguin. Ringwood,

Courier Mail. 1985. 'Strike Right Second to Power Need’. 17 April.

Deery, S. J. \& Plowman, D. 1991. Australian Industrial Relations. $3^{\text {rd }}$ edition. McGraw-Hill. Sydney.

Department of Labour (UK) (1993), Employment Gazette, December. 546

Edwards, P K \& Bain, G S. 1988. 'Why are Trade Unions Becoming More Popular? Unions and Public Opinion in Britain’. British Journal of Industrial Relations. 26(3). September. 311326.

Edwards, P K \& Bain, G S. 1990. 'Trade Union Popularity 1954-1988: A Reply to Marsh’. British Journal of Industrial Relations. 28(1). March. 66-68. 
Frenkel, S.J.\& Peetz, D. 1990. 'Enterprise Bargaining: The BCA's Report on Industrial Relations Reform’. Journal of Industrial Relations. 32(1). March, 69-99.

Gallie, D. 1989. 'Trade Union Allegiance and Decline in British Urban Labour Markets'. Working Paper 9, Social Change and Economic Life Initiative, Economic and Social Research Council. Oxford.

Hamilton, R. 1994. 'Employer Matters in 1993'. Journal of Industrial Relations. 36(1). March, 117-34.

Hancock Committee (Committee of Review Into Australian Industrial Relations Law and Systems). 1985. Australian Industrial Relations Law and Systems. Volume 2: Report. AGPS. Canberra.

Hartley, J.F. 1992. ‘Joining a Trade Union’. In J.F. Hartley \& G.M. Stephenson (eds.) Employment Relations: The Psychology of Influence and Control at Work. Blackwell. Oxford. 163-83.

Hunt, F.J. (ed) 1978. Socialisation in Australia. International Press. Melbourne.

Insight New Zealand. 1988. Industrial Relations Issues in New Zealand: A Survey of Public Attitudes. prepared for the New Zealand Business Roundtable. Insight New Zealand. Auckland. December. 
ISSS. various years. International Social Science Survey. Social Science Data Archives. Australian National University. Canberra.

Jones, R et al. 1993. Australian Electoral Study 1993. computer file, Social Science Data Archives, Australian National University. Canberra.

Jones, R et al. 1996. Australian Electoral Study 1996. computer file, Social Science Data Archives, Australian National University. Canberra.

Jordan , D. L. 1993. 'Newspaper effects on policy preferences'. Public Opinion Quarterly,; Summer,. 57(2), 191-204.

Kenyon, P.D.\& Lewis, P.E.T. 1992. ‘Trade Union Membership and the Accord'. Australian Economic Papers. 31(59). December, 325-345.

Marsh, D. 1990. 'Public Opinion, Trade Unions and Mrs Thatcher'. British Journal of Industrial Relations. 28(1). March. 57-68.

Mayer, W G. 1992. The Changing American Mind. University of Michigan Press. Ann Arbor.

McAllister, I \& Mughan, A. 1987. Australian Election Study 1987. computer file and codebook, Social Science Data Archives, Australian National University. Canberra.

McAllister, I, Jones, R \& Gow, D. 1990. Australian Election Study 1990. computer file and codebook, Social Science Data Archives, Australian National University. Canberra. 
Macintyre, S F (1983) ‘Labour, Capital and Arbitration’, in B W Head (ed) State and Economy in Australia, Oxford University Press, Melbourne.

McNair Anderson Associates \& Beed, T. 1983. The Changing Australian: A National Opinion Research Study. Sentry Holdings. Sydney.

McNair, I W (ed). 1988. Australian Public Opinion Polls (The Gallup Method) 1973-1987. Quadrant Research Services. Sydney.

Millward, N. 1990. 'The State of the Unions'. in R Jowell, S Witherspoon and L Brook with B Taylor (eds) British Social Attitudes: the Seventh Report. Gower. Aldershot. 27-50.

Moore, D (1989) 'Why the Accord has Failed', Proceedings of a Conference of the H.R Nicholls Society, Canberra, 24-26 February, available at http://www.hrnicholls.com.au/nicholls/nichvol6/vol69why.htm

Morgan Gallup Poll. 1974. 'Trade Unions'. Computer Printout 48. Melbourne. AugustSeptember.

1976. 'What Australians Think About Trade Unions'. 361A. May.

1977. 'Use the Arbitration Commission for Wage Negotiations'. special poll for channel

9. 10 May. 
1978. ‘Most Against Compulsory Unionism’. Finding 594. Melbourne. November.

Morgan Poll. 1992. 'Fewer Believe Trade Unions in Australia a Good Thing and Most Believe Trade Unions Have Too Much Power’. Finding No 2354. 14 December.

----- 1998a. 'Politicians Fall to Low Levels of Honesty and Ethics - Only Car Salesmen Rate Lower'. Finding No 3088. 21 May.

1998b. 'Australian Electors Divided on Patrick's Sacking of Waterfront Workers and Federal Government Involvement', Finding No. 3074. 21 April.

------ 2000. 'Nurses, Pharmacists and Doctors Most Respected Professions, Car Salesmen, Journalists and Real Estate Agents Least Preferred’. Finding No 3349. 9 November.

------ 2001. 'Federal Voting Intention Trend Since 1996 Federal Election - House of Representatives', http://www.roymorgan.com/polls/trend/vote96_.html.

Morris, A \& Wilson, K (1994) 'An Empirical Analysis of Australian Strike Activity: Further Evidence on the Role of the Prices and Incomes Accord', Economic Record, 70, 181-91.

----- (1995) ‘Corporatism and Australian Strike Activity’, Australian Bulletin of Labour, 21, $153-73$.

Mutz, K. 1997. 'Reading public opinion’. Public Opinion Quarterly, Fall 1997,. 61(2), 43151. 
NSSS (National Social Science Survey). various years. National Social Science Survey. Social Science Data Archives. Australian National University. Canberra.

----- 1989. 'International Opinion: Union Power'. National Social Science Survey Report. 1(3). January. 8.

Newspoll. 1986. 'Unions Too Powerful, Poll Shows’. Australian. 10 September.

------ 1987. ‘Compulsory Unionism Opposed by 73pc’. Australian. 19 March.

------ 1998. poll conducted 11-13 May, http://newspoll.com.au/cgi-bin/display_poll_data.pl.

Oskamp, S. 1977. Attitudes and Opinions. Prentice-Hall. Englewood Cliffs, NJ.

Peetz, D. 1996. 'Workplace Cooperation, Conflict, Influence and Union Membership'. in G Griffin (ed) Contemporary Research on Unions: Theory, Membership, Organisation and Non-standard Employment', Volume 2, National Key Centre in Industrial Relations, Monograph No 8, Melbourne, 309-346. 1998. Unions in a Contrary World. Cambridge University Press. Cambridge.

Rawson, D. 1978. Unions and Unionists in Australia. George Allen and Unwin. Sydney. 
------ 1983. ‘Is Unionism Everywhere in Decline?’ paper presented to Australasian Political Studies Association annual conference. August.

1992. ‘Has Unionism a Future?’ in M Crosby and M Easson (eds) What Should Unions Do? Lloyd Ross Forum/Pluto. Sydney. 2-15.

Workers Online. 2001. 'Survey shows majority support for unions'. Workers Online. 103. http://workers.labor.net.au/103/news1_survey.html.

Schwartz, A. 1966. What do You Think? E.P. Dutton \& Co. New York.

Sloan, J. 1994. 'Worse Might Be Better?’, in `From industrial relations to personal relations: the coercion of society', Proceedings of the XVIth Conference of the H.R. Nicholls Society, Melbourne, 2-3 December, available at http://www.hrnicholls.com.au/nicholls/nichvo16/vol16con.htm

Social Impacts/ Morgan Gallup Poll. 1983. Trade Union Business. Social Impacts \& Roy Morgan Research Centre. Melbourne.

Soutar, G N, Savery, L K \& Dufty, N F. 1985. 'Community Attitudes to Industrial Relations Issues in Perth, 1974-1984'. Journal of Industrial Relations. 27(1). March. 61-67.

Stewart, A. 1994. 'The Industrial Relations Reform Act 1993: Counting the Cost'. Australian Bulletin of Labour. 20(2). June, 140-61. 
Van de Vall, M. 1970. Labour Organisations. Cambridge University Press. Cambridge.

Webb, N. \& Wybrow, R. 1981. The Gallup Report: Your Opinions in 1981. Sphere. London.

Weimann, G. 1991. 'The Influentials: Back to the Concept of Opinion Leaders?'. Public Opinion Quarterly, Summer;. 55(2), 267-79.

Western, B. 1993. 'Postwar Unionisation in Eighteen Advanced Capitalist Countries'. American Sociological Review. 58. April, 266-82.

Windschuttle, K. 1981. 'Strikes and the Press'. in Keith and Elizabeth Windschuttle (eds) Fixing the News: Critical Perspectives on the Australian Media. Cassell. Sydney. 


\section{ENDNOTES}

${ }^{\text {i } A} 1998$ Newspoll, in which young Australians aged 13-19 years were offered a dichotomous choice ('good job'/‘poor job') did nothing to refute this trend: with 47 per cent saying unions were doing a good job for the nation and just 18 per cent saying they were doing a poor job (Newspoll 1998).

ii Similarly, a 1976 Age Poll found much more support for compulsory unionism than an APOP poll in the same year when the question was asked in the following format: 'Should the items in the list definitely be compulsory, probably be compulsory, probably not be compulsory or definitely not be compulsory?' (Age Poll 1976; Morgan 1978).

iii A comparable effect can be seen in SEMSE data: respondents were more likely to say that Australian unions have too much power if they believed that unions at the workplace were strong. iv The sample is 2000 per year, based on a combined interview/self-administered survey format. The exact wording of the questions is not revealed as it 'is copyright'. Figures are based on responses to each of two statements on a six point strongly agree-strongly disagree scale.

$v$ The proportion of people who both 'clearly agreed' that strong unions were essential and 'clearly disagreed' that unions had too much power and were a barrier to progress only rose slightly and non-significantly, from 28\% in 1997 to 29\% in 2001.

${ }^{\text {vi }}$ As part of a case study the SEMSE questionnaire was administered to workplaces in a multinational pharmaceutical company, Pharm, in both the UK and South Africa. Amongst employees in the British workplace, PharmUK, with an opinion, 44 per cent disagreed with the statement 'unions in this country have too much power', compared to 25 per cent of Australians in SEMSE who disagreed with the equivalent statement. Similarly, 40 per cent of employees in the South African workplace, PharmSA, disagreed with the statement. None of the 35 Australian workplaces in SEMSE had employees as strongly disposed to disagree with this statement as PharmUK and only two had employees as strongly inclined to disagree as PharmSA. While only 52 per cent of SEMSE respondents disagreed that the country would be better off without unions, 69 per cent of respondents in PharmUK and 56 per cent of employees in PharmSA disagreed. Details on SEMSE can be found in Peetz (1998a).

vii At the time, approximately twice as many people said that the dispute made them less likely to vote for the government as said that it made them more likely to vote for the government. On the Morgan poll, Government support (in two party preferred terms) fell by 6 percentage points between the first and second weeks of the dispute and, overall, fell from an average of $50 \%$ in the two months up to the end of the first week of the dispute, to $48 \%$ over the following two months. 
It reached 50\% again only once in the three years that followed (Morgan 1998b, 2001). 